\title{
Poland - Twenty Years With Market Economy
}

Gorm Jacobsen, University of Agder, Norway

\begin{abstract}
This article presents the main factors behind the developement of the Polish economy since the introduction of a market economy twenty years ago. First there is a decription of how the privatisation process actually took place. Then is followed by some information about the development of a financial market, i.e. the banking sector. At the end there is a summary of some of the main factors behind the huge inflow of foreign investments to Poland during this period.
\end{abstract}

Keywords: market economy, economic developement, transition economics, economic history

\section{INTRODUCTION}

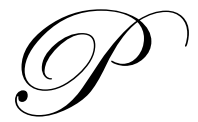

oland was one of the first post-socialist countries that changed from a central planning economy to a market economy. The new economic system was introduced on January 1, 1990.

The Polish economy like the economy for many other post-socialist countries was characterised by disequilibrium in almost every market. Most people had to use a great part of their time queuing up to buy what was necessary for their daily life.

The transformation of the Polish economy to a market economy led to a deeper recession than expected during the two first years of the transformation process. The GDP decreased by 18,3 per cent from an already low level. In the same period the level of unemployment reached more than 2000000 people (11,8 per cent), and the consumer prices increased by almost 1070 per cent.

During the period 1990 - 2008 the average annual growth rate in the GDP has been 2,9 per cent. If we look at the period $1992-2008$, after the big recession due to the adoption of the new economic system, the GDP shows an average annual growth rate of 4,5 per cent.

As a whole the introduction of a market economy has made Poland to become one of the countries in Europe with the strongest economic growth over a period of almost two decades. economy:

In this article I will give a description of the main factors behind the successful development of the Polish

1. The privatisation process.

2. The development of the banking system.

3. Foreign direct investments.

\section{THE PRIVATISATION PROCESS}

A significant part of the introduction of a market economy was the privatisation of state owned enterprises.

Its core aim was to restructure and modernise the economy and to lay the foundations for the acceleration of economic growth. 
The privatisation of state enterprises was expected to result in profitable businesses, creation of new jobs and effective use of resources.

To reach these goals it was also necessary to develop a functioning financial market, and invest in infrastructure, especially telecommunication, roads, railways and airports.

In the period between August 1, 1990 and December 31, 2008 the privatisation process was started in 5909 out of 8457 state owned enterprises registered in July 1990.

Even if the privatisation process has been a success there have also been major obstacles during this process. Some of the problems faced by the authorities during this process are as follows:

- unsatisfactory financial and economic situation of the enterprises offered for privatisation

- $\quad$ uncertain legal status of enterprises

- lack of agreement among various trade unions functioning in the enterprise, regarding selection of potential investors

During two decades of privatisation, the process has been completed in the following sectors: telecommunications, trade and services, the automotive industry, household appliances, construction, electrical engineering, cement production, wood processing and furniture manufacturing, food processing and tobacco industry.

The privatisation has been almost completed in banking, insurance, and in industrial sectors such as the pharmaceutical, sugar, spirits, shipbuilding, transport, oil, electric energy, metallurgy and publishing industries. recently.

In sectors such as coal mining, gas, heavy chemicals and defence the privatisation has been launched only

Sectors and enterprises of strategic importance for the Polish economy, such as seaports, airports, railway lines, electric energy transmission networks, gas and oil pipelines, and backbone telecommunications network will remain in state ownership.

The main methods to transfer state enterprises and assets to private ownership were direct and indirect (capital) privatisation.

\subsection{Direct privatisation}

Direct privatisation is largely aimed at providing opportunities for rapid ownership changes in small and medium state enterprises.

The direct privatisation is decentralised, where the main work in the privatisation process is carried out by 16 province governors of the Treasury and Transport Departments. Still the whole process is controlled and supervised by the Ministry of the Treasury.

In most of the cases the privatisation is executed by:

\section{Sale of enterprise}

This is recommended particularly for enterprises in a poor economic situation, particularly those in need of new investments.

The investors are selected by way of public tender or public invitation to negotiations. 
Twenty per cent of the amount has to be paid by the investors when buying a state enterprise. The remaining amount can be paid in instalments over a period of up to five years. In this period the investors have to pay interests of the remaining debt.

Fifteen per cent of the price has to be paid to the company social benefit fund (CSBF) on the day the contract is signed. The remaining 85 per cent are paid to the Treasury Department.

Contribution of an Enterprise to a company

This form of privatisation is primarily used in privatising enterprises which need substantial financial outlays. The sale of the enterprise is done to investors selected by way of public invitation to negotiations.

This company may take the form of a joint-stock company or a limit liability company. The private shareholders are obliged to make contributions for at least 25 per cent of the new company's initial capital.

Giving of Enterprise to be used for Consideration-Employees buy-outs (leasing)

In this case the Treasury rents an enterprise to a company with the participation of employees in this enterprise. This agreement cannot exceed a period of 15 years. After this period the company may take over the whole enterprise with the exclusion of public procedures.

To ensure an appropriate influx of capital to be used for development and investments, the privatisation law requires that at least 20 per cent of the original capital of a company should be acquired by persons who do not work in the enterprise. These investors however may take part in the management of the company.

\subsection{Indirect privatisation}

On the initiative by the Ministry of the Treasury, or at the request of the enterprise itself a state enterprise may be transformed into a joint stock company or a limit liability company - the so-called commercialisation or indirect privatisation. The company is a legal successor of the state enterprise.

After the commercialisation the Treasury is the owner of 100 per cent of the stakes in the company.

Prior to selling parts of a company, the company is subject to a thorough analysis and valuation. There is also often carried out an analysis of the entire sector and the market for these products on domestic and foreign markets.

The employees receive up to 15 per cent of the shares for free. These can be sold after a two-year period.

In most of the cases the privatisation is executed by:

\section{Public offering}

This means offering shares for sale on the Warsaw Stock Exchange (WSE).

An independent and reliable advisory firm, publish all relevant information of the company in a prospectus. Then in order to sell the shares there is a promotional campaign in the press, radio and television. In some cases there are also arranged presentation for major investors and their advisors.

\section{Public tender}

Public tender means an invitation selected by the Treasury to submit their offers for the purchase of a substantial block of shares or stakes in a Treasury-owned company. 
In this procedure the Treasury specifies the minimum number of shares an investor must buy, the minimum price for one share, the minimum investment and social commitments. The period for which the potential investor is bound by his offer is also specified.

The advertisements are published in major country-wide newspapers, normally every month.

By the deadline specified in the advertisement, potential investors must submit information and deposit a surety. Once the deadline for submission of offers expires, the Tender Commission appointed by the Ministry assesses the quality of submitted offers and selects the bidder who submits the best offer. Then the sales agreement is signed by the Minister of the Treasury. A buyer who withdraws from the agreement will lose the surety.

\section{Negotiations based on a public invitation}

Privatisation advisors of the Ministry of the Treasury participate in the negotiations. Here the negotiations are about the number of shares, price per share, terms of payment, investment commitments, the social package and other conditions.

In situations with many potential investors, the number is limited to two or three after preliminary negotiations. The details of the agreement are then worked out with the buyer.

Increase in the initial capital

In this method the company issues new shares for sale in the private sector of the economy.

This method is used for companies facing the threat of bankruptcy, and then is in need of increased capital.

\section{Liquidation of state enterprises}

State enterprises which incur losses and do not have the potential for profit are eliminated from the market through liquidation.

Still profitable parts of enterprises can be sold to private owners.

\section{THE DEVELOPMENT OF THE BANKING SECTOR}

The introduction of a well functioning financial market has been of crucial importance in the transformation of the Polish economy into a market economy.

The work on restructuring the banking sector started in 1987, i.e. when Poland still had a socialist economy. This work resulted in "the Banking Act" and "the Act on the National Bank of Poland" carried out by the Sejm on 31 January 1989. This resulted in a two-tier banking system - i.e. a central bank and commercial banks - which is characteristic for a market economy.

In addition to NBP the following specialised banks were operating by the end of 1988 :

- $\quad$ Bank Gospodarki Zywnosciowej (BGZ) - a state-cooperative bank, serving the food and agriculture industry established in 1975. It was transformed into a joint stock company (commercialized) in 1994.

- $\quad$ Bank Polska Kasa Opieki SA - a one hundred per cent state owned joint stock company, performing mainly foreign currency operations for the public. This bank was established in 1929.

- $\quad$ Bank Handlowy w Warszawie SA - a one hundred per cent state owned joint stock company. This is the oldest bank in Poland, operating since 1870. This bank was servicing Poland's foreign turnover, particularly for governmental transactions.

- $\quad$ Powszechna Kasa Oszczednosci - separated from the NBP in 1987 to service retail customers. 
- $\quad$ Bank Gospodarstwa Krajowego, established in 1924, between 1945 - 1989 operating on a limited scale (special purpose for governmental operations).

- $\quad$ Bank Rozwoju Eksportu SA - which took up the operation in 1987.

In addition 1663 cooperative banks affiliated to the BGZ were operating.

\subsection{The period $1989-1992$}

In the Act of 31 January 1989 conditions to establish new banking institutions were created. Apart from state and cooperative banks, private banks were also allowed to be established.

Due to the introduction of a market economy the administrative methods used in the monetary policy were replaced by economic tools like interest rates, exchange rates, required reserves and open market operations.

The removal of the banking sector monopoly started with the establishment of nine commercial banks (separated from the NBP) as of February 1, 1989. These banks were:

- $\quad$ Powszechny Bank Gospodarczy w Lodzi
- $\quad$ Oowszechny Bank Gospodarczy w Warszawie
- $\quad$ Bank Slaski w Katowicach
- $\quad$ Bank Zachodni we Wroclawiu
- $\quad$ Bank Gdanski w Gdansku
- $\quad$ Bank Depozystowo-Handlowy w Krakowie
Pomorski Bank Kredytowy w Szczecinie

These nine banks were assigned the network of previously NBP branches, usually in a given region. Originally they were state banks equipped with capital (own funds) by the NBP. In 1991 they were transformed into sole state shareholder companies. In 1993 the tenth bank - Polski Bank Inwestycyjny SA was separated from the NBP.

Head offices were located in the cities of the greatest business activity as that was expected to stimulate the economic development of these regions.

Both public and private capital participated in the establishment of new banks. During the period 1989 1992 a total of 70 banks were established.

In this early stage of the transformation process of the Polish economy numerous banks went bankrupt or were liquidated. Some also lost their independence as a result of take-over by other entities.

In addition to private sector, units in the state administration played a certain role in establishing new banks, since they saw this as a way of accomplishing their social and economic goals. Some of the new bank establishments were:

- $\quad$ Bank Gospodarstwa Krajowego (a state bank) was reactivated by the minister of Finance to conduct state business transactions.

- $\quad$ Bank Rozwoju Budownictwa Mieszkaniowego SA on the initiative of the Ministry of Building Industry was established to finance the housing construction industry.

- $\quad$ Bank Inicjatyw Spoleczno-Ekonomicznych SA was established as a result of the initiative of the Ministry of Labour. The aim was to create new jobs for the unemployed by supporting the development of small and medium sized enterprises. The capital originated primarily from the Labour Fund.

- $\quad$ Bank Ochrony Srodowiska SA was established to finance pro-ecological investment projects from the funds of the National Fund for Environmental Protection. 
- $\quad$ Bank Wlasnosci Pracowniczej SA was aimed to support privatisation and employees ownership.

During the years these banks were forced to transfer into institutions of more commercial and universal character.

Some banks were established to provide the servicing and financing selected sectors of the economy. Other banks were established as a result of local initiatives to support the development of a given region. Many of these banks became targets for takeover by larger banks due to a weak financial situation. This was a result of the development of the economic situation in the given sector or region of the economy.

During the period 1990 - 1992 seven joint-stock companies with a majority shareholding of foreign investors were established. Special tax relief during the first three years of operations, the possibility of holding the capital in foreign currency, and the freedom of transferring a 15 per cent profit were some of the factors encouraging foreign investors.

The first foreign bank established in Poland was Bank Amerykanski w Polsce SA (American Bank of Poland). 80 per cent of the bank was American owned and 20 per cent Polish owned. The bank was established in December 1989.

\subsection{The period 1993-1999}

The number of commercial banks rose quickly during the first years after the introduction of a market economy. The number of banks reached its maximum number by the end of 1993 with 87 banks.

At the beginning of this period many of the newly established banks were threatened with bankruptcy due to weak financial standings for many of these banks. Due to the transformation of the Polish economy to a market economy, the GDP was reduced by 11.6 per cent and 7.6 per cent in 1990 and 1991 respectively. At the same time the state stopped subsidising many state enterprises. These changes resulted in a deterioration of the financial position of a huge number of companies. As a result Poland experienced a crisis in the banking sector. This crisis was strengthened as a result of low equity (own capital) in many banks. Furthermore there was lack of professionalism in part of the managerial staff of the banks.

During this period the main objective of the NBP was the strengthening of the banking sector through the restructuring of domestic banks threatened with bankruptcy and with the assistance of foreign banks.

The competition in the banking sector, and the capital necessary to obtain authorisation - equivalent to 5 million Euro - reduced the opportunities for Polish banks with only Polish capital to enter the market.

During these years there was a significant increase in the number of banks with a major part of foreign capital, while there was a similar reduction in the number of banks with a major part of Polish capital, and banks with a major part of state capital.

The reduction in the number of banks with over 50 per cent of state capital was mainly a result of the privatisation process taking place during this period.

During this period banks with a majority owned by the government fell from 29 to 7 , while the number of private banks increased from 58 to 70 . During the same period banks with a major part of foreign equity increased from 10 to 39 .

\subsection{The period $2000-2008$}

During this period the number of commercial banks was reduced from 77 to 70 units. The number of cooperative banks was reduced from 781 to 579 during the same period. 
By the end of 2008 the cooperative banks' share in the sector's assets amounted to 6.0 per cent. The share of loans and deposits constituted 6.3 per cent and 8.5 per cent respectively.

There has also been a slight decrease in the number of banks under foreign capital in the same period, while there has been a significant reduction in the number of commercial banks under domestic control. The reduction in the number of banks under foreign control is due to Poland's membership in the EU from May 1, 2004. From this moment banks licensed in other EU-countries could operate in Poland, but were not registered in the statistics as foreign banks.

Foreign investor's posses more than 71 per cent of total banking assets in Poland. The biggest investors are banks from Italy, which hold more than 14 per cent of the assets, followed by banks from the Netherlands (11.3 per cent) and banks from Germany ( 9.6 per cent) and the USA ( 8.2 per cent).

In total investors from 17 countries were operating in this sector by the end of 2008 .

\section{FOREIGN DIRECT INVESTMENTS}

Since the beginning of the 1990s Poland has been a leading country in Central and Eastern Europe in terms of the volume of Foreign Direct Investment flow.

As a member of the OECD (1997), the NATO (1999) and the EU (2004) Poland is a trustworthy and reliable partner for international business.

Since the introduction of a market economy from January 1, 1990 foreign companies have invested more than USD 92 billion by the end of 2005 .

These figures are presented by the Polish Agency for Foreign Investment (PAIZ), and according to the definition of FDI, it includes entities with foreign capital of value exceeding USD 1 million and at least 10 per cent foreign ownership. These are registered in detail. The value of capital invested by entities with the participation of foreign capital not exceeding USD 1 million has been estimated by the PAIZ.

For the years after 2005 figures for FDI have been registered by the National Bank of Poland. During the three-year period 2006 - 2008 the total value of FDI amounted to more than Euro 43 billion.

\subsection{Why invest in Poland?}

There may be many economic and political reasons for foreign companies to invest in Poland. These factors will be discussed below.

The Polish Information and Foreign Investment Agency (PAIiIZ)

PAIiIZ was established in June 2003 as a result of the merger of the Polish Agency for Foreign Investment (PAIZ) and the Polish Information Agency (PAI) to coordinate the economic promotion of Poland.

The PAIiIZ encourages foreign corporations to make investments in Poland. It serves to help them deal with all the administrative and legal procedures encountered during the investment process.

Among other things PAIiIZ offers investors:

- $\quad$ quick access to complex information regarding economic-legal investment environment

- $\quad$ help in finding suitable partners and suppliers, and attractive investment locations

- $\quad$ advice during each phase of the investment process

PAIiIZ has created Regional Investor Assistance Centres around Poland. 


\section{Political stability and dynamic development}

Poland's safety and trustworthiness is secured by its membership in the OECD (1997), the NATO (1999) and the EU (2004).

The EU integration creates new opportunities for foreign investors in Poland

- $\quad$ they gain unlimited access to the EU-market, including Norway, Iceland and

- $\quad$ Liechtenstein more than 460 million customers.

- $\quad$ Poland will be the single largest beneficiary of EU aid among the acceding countries.

- $\quad$ Polish law will be further harmonised with EU-rules, making the legal environment fully compatible with Western standards.

Education and labour force

Poland is one of Europe's youngest societies and is also one of the best educated societies in Europe. There are 126 public universities and colleges, as well as 301 private schools of post high school education.

Two million people are currently studying at university level; almost half of the student age population. The number of graduates per year during the last years have been around $350000-400000$ people. Many of these students have good skills in foreign languages like English, German and Russian, among others.

Since the introduction of a market economy the disequilibrium in the labour market has been the biggest single problem in the Polish economy. Even with a falling unemployment rate since 2003, there are still around 1500000 unemployed people, or almost $10 \%$ of the labour force. As the restructuring processes continue the unemployment is expected to decrease further.

Due to a high unemployment rate and the high level of education among young people there are relatively easy for businesses to find qualified workers without rising wages.

The average gross wages are lower in Poland than both in the Czech Republic and in Hungary.

Poland also has competitive prices in Real estate.

Also when it comes to the energy market, prices of electricity and gas are lower than in Western Europe.

Location

Poland remains one of the most preferred locations for investments. Poland is sometimes called "The heart of Europe". Investments in Poland give companies the opportunity of direct access both to the markets in Western Europe (almost 500 million people) and to Eastern Europe (around 250 million people).

The infrastructure has been significantly improved since the beginning of the transformation process.

There are international airports in Warsaw, Lodz, Krakow, Katowice, Poznan, Wroclaw, Szczecin and Gdansk. This makes it possible to reach the majority of European cities within two-three hours.

The road network has been under continuous development for the last fifteen years. And thanks to the EU membership, structural funds will be used to further construct a high quality road infrastructure.

EU is also supporting the development of the railway system. There are fast, reliable connections with Russia and other Eastern European countries as well as Western Europe.

The rivers Odra, Vistula, Warta and Notec are used for the transportation of some goods. 
Main ports along the Baltic sea are located in Gdansk, Gdynia, Kolobrzeg, Szczecin and Swinoujscie.

\section{International schools}

In the 1990s many international schools with a high quality of education were established in Poland. This makes Poland well prepared for hosting foreigners who want to settle with their families in Poland.

\subsection{Regions}

Voivodships

As a result of the administrative reforms taking place in 1999, Poland was divided into 16 administrative units (voivodships).

The voivodships work out and implement regional development strategies which include international economic relations.

Special Economic Zones (SEZ)

There are 14 Special Economic Zones in Poland. The purpose of SEZ is to support regional development. A Special Economic Zone is a designated area in which manufacturing and distribution activities can be conducted on preferential terms. These were created to:

- $\quad$ accelerate the economic growth of Polish regions

- $\quad$ develop and use the most modern technological solutions in the national economy

- $\quad$ increase the competitiveness of products and services

- $\quad$ encourage the creation of new jobs

The Zones' management issues permits for business activity in a given SEZ and helps in the investment process through facilitating contacts with local authorities or the central administration in such areas as purchase of land, for example.

SEZ-based entrepreneurs can take advantage of two kinds of regional aid:

i) Regional aid to support new investment projects. The costs qualifying for aid are

$\circ$ purchase of land

$\circ$ expenditure on buildings and structures

- expenditure related to equipment for facilities with tangible assets (machinery and related devises, tools and instruments, equipment for office work, technical infrastructure)

ii) Regional aid for employment. The amount of regional aid allocated to job creation is calculated on the basis of two years' labour costs of newly-employed staff borne by the entrepreneur, consisting of gross payroll costs and mandatory charges related to their employment

Apart from the above incentives, companies investing in the SEZ are among other things also often granted exemption from real estate tax by local authorities.

Entities that are willing to take advantage of SEZ incentives can take advantage of the state subsidy mentioned below.

The amount of aid allowed on most of Poland's territory is 50\%, except for

- $\quad$ Krakow, Wroclaw and the Gdansk-Sopot-Gdynia agglomeration - 40\%

- Warsaw and Poznan -30\% 
The $50 \%$ rate means that when investing in a zone, entrepreneurs may obtain aid not exceeding $50 \%$ of investment outlays. For small and medium enterprises as defined by the Economic Freedom Act, the index is increased by 15 percentage-points to $65 \%, 55 \%$ and $45 \%$ respectively.

Many of these entrepreneurs can also apply for aid from the EU structural funds.

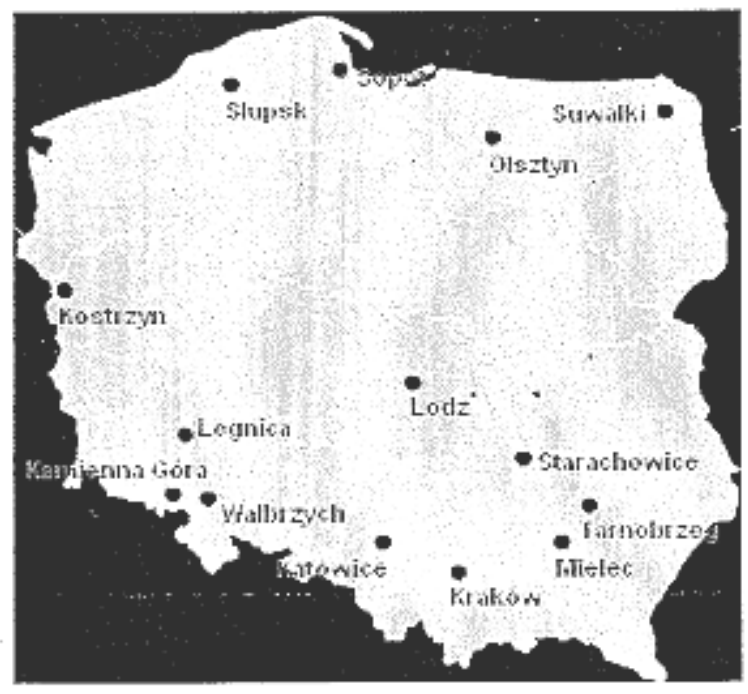

Special Economic Zones map

(Source: www.paiz.pl)

\section{Regional Investor Assistance Centres}

There are seventeen such centres around Poland. The aim is to improve the quality of investor service in the region, providing access to the latest information such as investment offers and microeconomic data. These offices which are financed by the regional authorities, also serve as links between the investor and the local authorities.

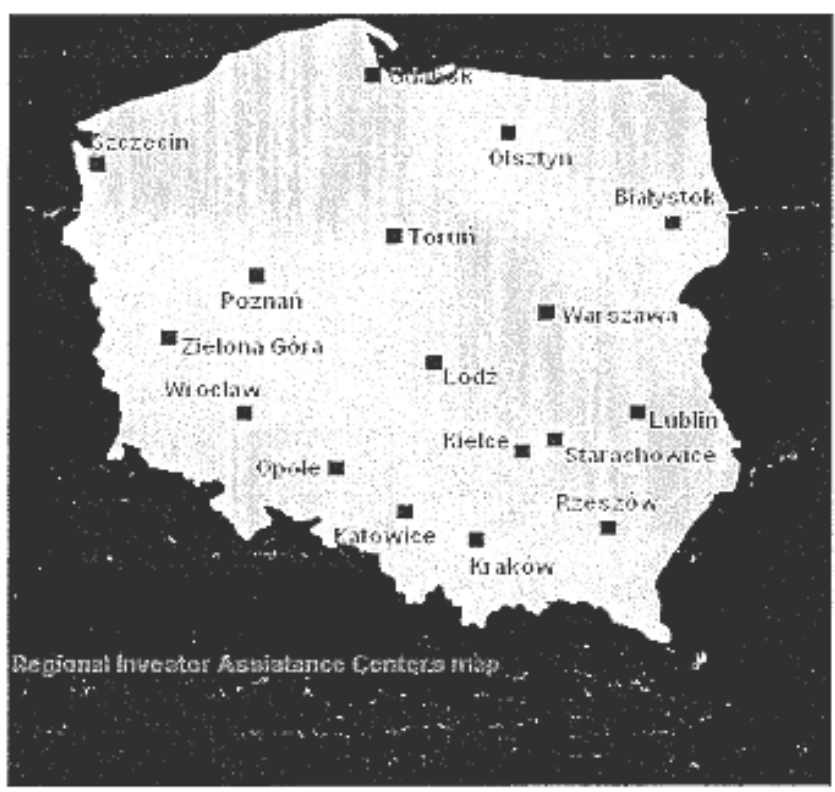

Regional Investor Assistance Centres map (Source: www.paiz.pl) 
Industrial and Technology Parks

There are 32 such parks so far in Poland. These are parks which are attractive for new investors, and already count of a high concentration of different kinds of industry.

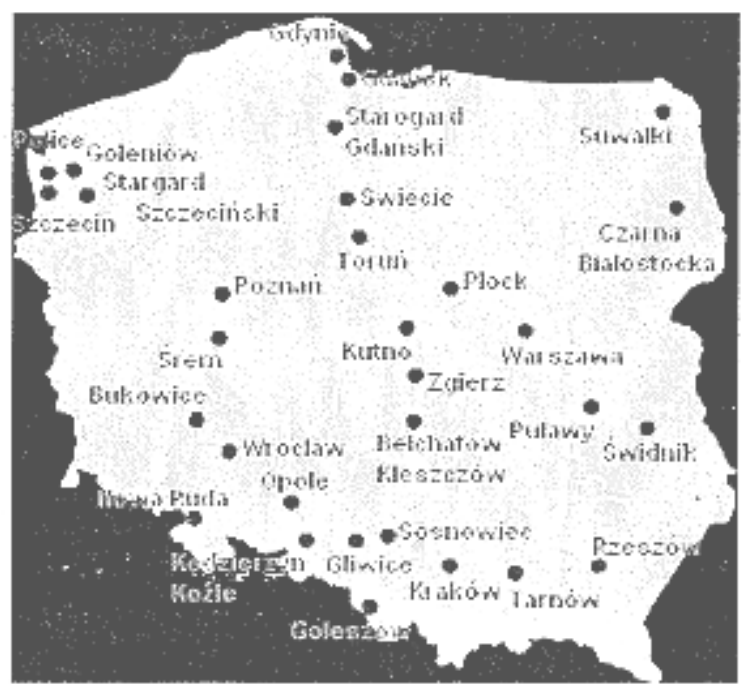

Industrial and Technology Parks

(Source: www.paiz.pl)

\subsection{FDI Stock and inflow during the period 1993-2008}

By the end of 2005 foreign companies have invested more than USD 92 billion according to figures presented by the Polish Information and Foreign Investment Agency (PAIZ).

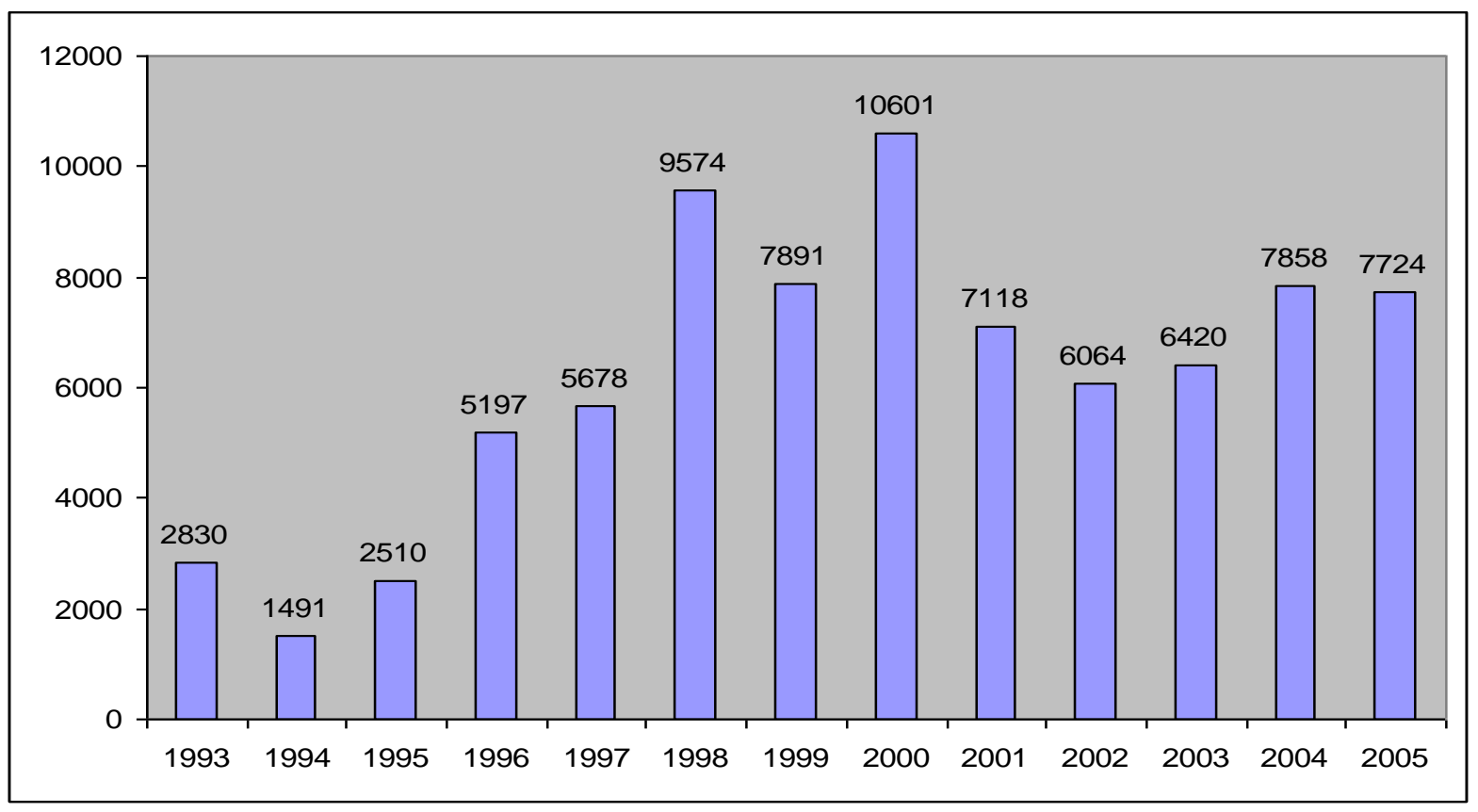

Figure1 FDI per year in million USD. 
For the years after 2005 figures for FDI are published by the National Bank of Poland (NBP). During the three- year period 2006 - 2008 the total value of FDI amounted to more than Euro 43 billion.

In 2006 the value was record high with Euro 15741 million, and increased to even new record high of Euro 16674 million one year later. This was due to strong economic growth for many years and an optimistic view of the future. As a result of the crisis in the World Economy the FDI was reduced to Euro 10970 million one year later.

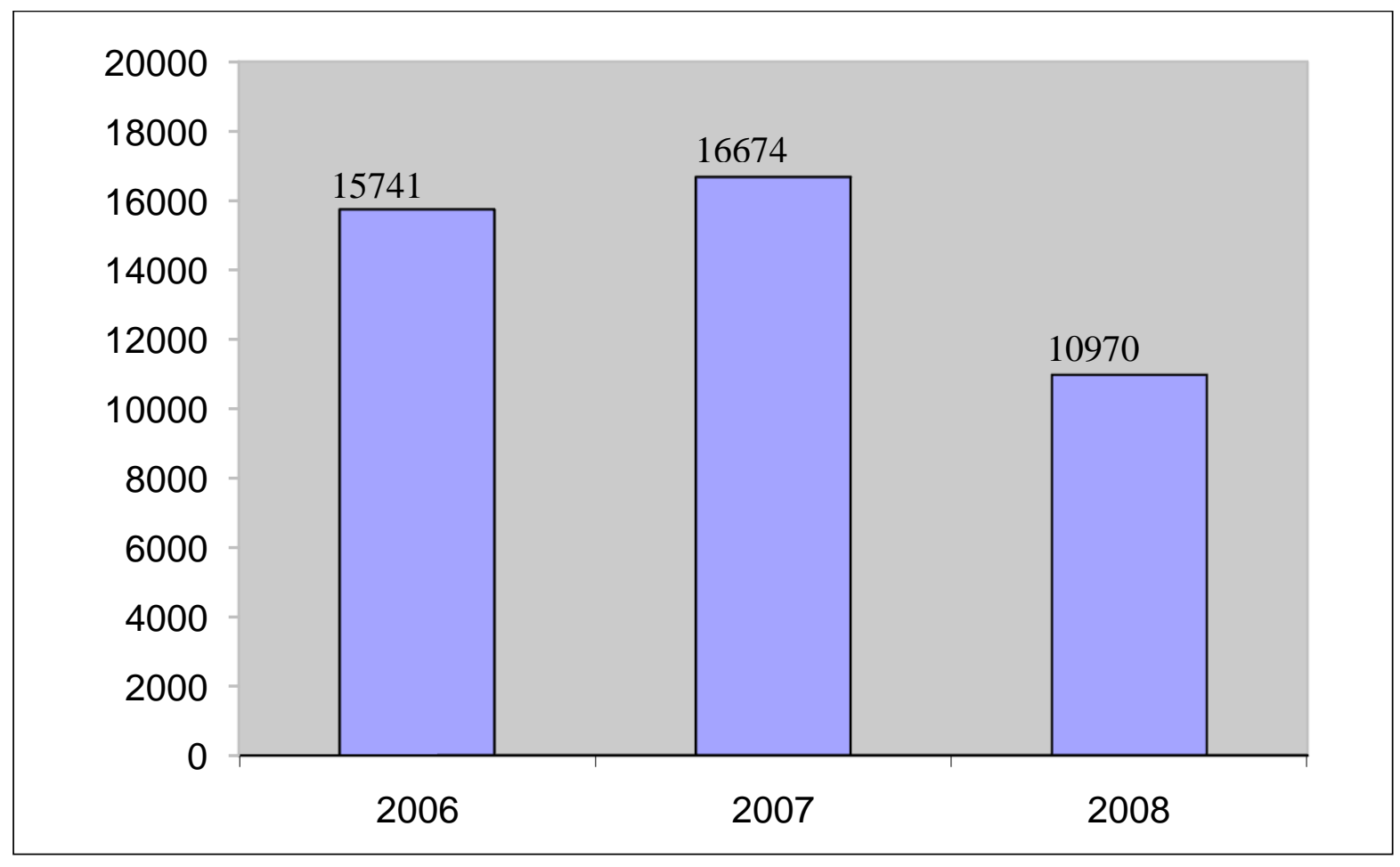

Figure 2. FDI per year 2006 - 2008 in million Euro.

Due to general economic policy and more specific economic policy by the Polish Government for almost twenty years, more than 1500 companies from 42 countries have invested more than USD 1 million each. They are recorded in the so called "List of major Foreign Investors in Poland."

In total the Polish Statistical Office (GUS) has registered 18515 companies with foreign capital by the end of 2007.

\section{CONCLUDING REMARKS}

Twenty years after the beginning of the transformation process the standard of living is far behind most OECD countries, measured in GDP per capita (PPP). With an average annual growth rate in the GDP of 3.5 per cent the next twenty years, the standard of living will be around the average level of the OECD countries today.

Except from the last year the level of unemployment has been decreasing since 2003. The greatest problem in the Polish economy is still the disequilibrium in the labour market. By the end of 2008 the number of unemployed people was 1474000 or, 9.5 per cent.

In spite of the crisis in the World economy OECD still expects the GDP to increase by 1.4 per cent in 2009 and by 2.5 per cent in 2010 . 
The implemented policy enabled Poland to transform its economy into one of the most robust ones in Central and Eastern Europe. As a whole this policy has made Poland into one of the countries in Europe with the strongest economic growth for many years.

Table 1 Privatisation revenues; Million USD.

\begin{tabular}{|c|c|c|c|}
\hline Year & Revenue* & Indirect privatisation & Direct privatisation \\
\hline 1991 & 171 & 141 & 134 \\
\hline 1992 & 373 & 239 & 159 \\
\hline 1993 & 434 & 274 & 147 \\
\hline 1994 & 725 & 578 & 169 \\
\hline 1995 & 1101 & 932 & 374 \\
\hline 1996 & 1442 & 1068 & 112 \\
\hline 1997 & 2043 & 1931 & 126 \\
\hline 1998 & 2079 & 1947 & 100 \\
\hline 1999 & 3422 & 3320 & 88 \\
\hline 2000 & 6263 & 6161 & 69 \\
\hline 2001 & 1666 & 1577 & 61 \\
\hline 2002 & 703 & 634 & 76 \\
\hline 2003 & 1065 & 1004 & 86 \\
\hline 2004 & 2806 & 2730 & 113 \\
\hline 2005 & 1189 & 932 & 78 \\
\hline 2006 & 201 & 87 & 67 \\
\hline 2008 & 695 & 547 & 2092 \\
\hline
\end{tabular}

Source: Ministry of the Treasury.

*) Total revenue may comprise, apart from revenues from direct and indirect privatisation, some additional sources. Thus the total may in some cases be larger than the sum of direct and indirect privatisation.

Table 2 Number of banks

Panel A

\begin{tabular}{|l|c|c|c|c|c|c|c|c|}
\hline Year & 1993 & 1994 & 1995 & 1996 & 1997 & 1998 & 1999 & 2000 \\
\hline Commercial banks & 87 & 82 & 81 & 81 & 81 & 83 & 77 & 73 \\
\hline i) with majority of public sector interest & 29 & 29 & 27 & 24 & 15 & 13 & 7 & 7 \\
\hline ii) with majority of private sector interest & 58 & 53 & 54 & 57 & 66 & 70 & 70 & 66 \\
$-\quad$ under domestic control & 48 & 42 & 36 & 32 & 38 & 39 & 31 & 20 \\
$-\quad$ under foreign control & 10 & 11 & 18 & 25 & 28 & 31 & 39 & 46 \\
\hline iii) Branches of credit institutions* & & & & & & & \\
\hline Cooperative banks & 1653 & 1612 & 1510 & 1394 & 1295 & 1189 & 781 & 680 \\
\hline Total banking sector & 1740 & 1694 & 1591 & 1475 & 1376 & 1272 & 858 & 753 \\
\hline
\end{tabular}

\section{Panel B}

\begin{tabular}{|l|c|c|c|c|c|c|c|c|}
\hline Year & 2001 & 2002 & 2003 & 2004 & 2005 & 2006 & 2007 & 2008 \\
\hline Commercial banks & 69 & 59 & 58 & 57 & 61 & 63 & 64 & 70 \\
\hline i) with majority of public sector interest & 7 & 7 & 6 & 5 & 4 & 4 & 4 & 4 \\
\hline ii) with majority of private sector interest & 62 & 52 & 52 & 49 & 50 & 47 & 46 & 48 \\
- under domestic control & 16 & 7 & 6 & 8 & 7 & 7 & 6 & 6 \\
$-\quad$ under foreign control & 46 & 45 & 46 & 41 & 43 & 40 & 40 & 42 \\
\hline iii) Branches of credit institutions* & & & & 3 & 7 & 12 & 14 & 18 \\
\hline Cooperative banks & 642 & 605 & 600 & 596 & 588 & 584 & 581 & 579 \\
\hline Total banking sector & 711 & 664 & 658 & 653 & 649 & 647 & 645 & 649 \\
\hline
\end{tabular}

Source: National Bank of Poland

*)Banks licensed in other EU - countries, operating in Poland. 


\section{AUTHOR INFORMATION}

Gorm Jacobsen has bachleor degree in business administration from University of Lund in Sweden (1977), and master degree in economics from University of Oslo in Norway (1986). Currently has position of Associate Professor of economics at Departement of Working life and Innovation, Faculty of Economics and Social Sciences at University of Agder in Norway.

\section{REFERENCES}

1. http://www.paiz.gov.pl/20090105/2009 fdi_inflow to poland

2. http://www.paiz.gov.pl/why poland

3. http://www.paiz.gov.pl/publications/foreign_investors_in_poland

4. http://www.paiz.gov.pl/about us

5. $\quad$ Privatisation Quarteley 2007. Ministry of the Treasury 2008.

6. Reports on the condition of Polish banks in 2008. The Polish Financial Supervision Authority 2009.

7. Summary of the Financial Situation of Polish Banks 2006. National Bank of Poland 2007.

8. The Polish banking system in the Nienties. National Bank of Poland 2001. 